\title{
First aid at the scene in the opinion of the members of Warsaw medical rescue teams
}

\begin{abstract}
Introduction. The ability to provide first aid should be one of the basic skills of each of us.

Aim. The aim of the study was to learn the opinion of the members of Medical Rescue Teams (MRT) of the "Meditrans" Provincial Ambulance and Sanitary Transport Service (PA and STS "Meditrans") in Warsaw on how people react in real situations threatening life or health of the injured person.

Material and methods. The study was conducted in the third quarter of 2015 on 335 members of medical rescue teams, including 77 women and 258 men, who provided medical services in the "Meditrans" Provincial Ambulance and Sanitary Transport Service MRT in Warsaw. The research tool was an anonymous questionnaire survey of own design, which consisted of 12 questions: closed, half open and one open question.

Results. The majority of respondents have encountered instances of first aid provision, but respondents assessed the frequency of such situations as low. Among the largest group of witnesses providing first aid there are the elderly and youth, who are subjected to various forms of education related to first aid provision.

Conclusions. Only continuous education and in particular, practical trainings will help people to overcome the barrier of their limitations in order to help others.
\end{abstract}

Keywords: First aid, emergency medical services, basic life support.

DOI: $10.1515 /$ pjph-2017-0002

\section{INTRODUCTION}

The ability to provide first aid should be one of the basic skills of each of us. First aid, by the Law on National Medical Emergency dated 8 September 2006 as amended, is a set of actions undertaken to save a person at the scene of an accident [1]. In Poland, on the basis of Article 162 of the Criminal Code, we are obliged to provide first aid to the victim. In addition, according to a large part of society, unselfishness towards others in need of help is our moral obligation [2]. Thus, it should be noted that neither the law nor the expectations of the society, preclude us to be inactive in a situation where somebody's life or health is threatened. Therefore, it is important to have knowledge of the principles and practical skills of providing medical aid by witnesses of an accident. In the era of healthy lifestyle popularity, including demonstrating the significance of first aid promoted by all sorts of social campaigns including TV series, such as 'ER', 'For good and for bad', 'On the siren', 'Rescuers', 'Hospital' and many others using in their background medical community. Public education begins at the kindergarten stage, where meetings with the representatives of the emergency services teach children proper behavior in emergencies, like when and how to properly call the appropriate emergency services. Subsequently, more extensive training programs appear in primary schools, secondary schools and post-secondary units during which practical techniques of first aid are introduced in the scope adjusted to the age of the youth. However, the most educational emphasis is placed on the training of young people (mostly students, scouts), and certain professional groups (mainly firefighters, teachers). Constantly disseminated knowledge about first aid should influence social approach to broadening the knowledge about this issue through the ease of access to training in basic life support (BLS) with the use of an automatic external defibrillator (AED) and thematic materials, as well as through all sorts of web portals and the possibility to install free applications for smartphones with the necessary first aid pieces of advice. High attention in the literature has been devoted to research aimed at controlling the knowledge about first aid. The authors of works that focused on the state of knowledge of particular social or occupational groups clearly showed that the level of knowledge about first aid is insufficient [3-6] and it needs to be systematically complemented and updated [7-10]. They stressed that trainings in first aid are surely justified, but they should put a greater emphasis on the practical part and optimally they should be conducted by professionals. Then, there is a chance that they would be more effective. At the same time, they highlight the fact in their studies that such courses should be mandatory, cyclic and optimally organized free of charge. In Europe, health emergency conduct algorithm

${ }^{1}$ Department of Medicine of Disasters, Medical University of Warsaw, Poland

${ }^{2}$ Department of Culture of Security and Methodology, Siedlce University of Natural Sciences and Humanities, Poland 
issued by the European Resuscitation Council (ERC). Knowledge in this scope is constantly changing based on successive research studies, resulting in a verification of these procedures. ERC also introduces algorithms as how to prepare instructors and conduct training in BLS, BLS-AED and first aid. In 2015, the scope of conduct with a conscious patient was introduced to trainings $[8,11,12]$. In their opinion, it is also worthwhile to pay attention during trainings to the noble idea, the attitude of first aid to injured persons, and additionally to fight the stereotype that by our ignorance we can worsen the condition of the injured person. However, as shown by the results of public opinion survey, many Poles are still not able to provide first aid. During the study, most of the respondents declared knowledge of first aid, which is more than it is in reality. One can often encounter the thesis, mainly among skilled professionals, that first aid provided by the witnesses is the weakest link in the system of national emergency medical services. Therefore, we conducted a survey among members of the medical rescue teams - MRT, who every day encounter the phenomenon of providing or non-providing first aid to people in lifeor health-threatening emergency. This will allow to answer the questions: How is it in reality? Does long-term emphasis on public education in this field provide tangible results? Are the knowledge and practical skills of witnesses unambiguous and increasing the chances of the victim?

\section{AIM}

The aim of the study was to learn the opinion of the members of the "Meditrans" Provincial Ambulance and Sanitary Transport Service (PA and STS "Meditrans") in Warsaw on the following questions: how does public react in real situations threatening life or health of the injured person? What emergency activities are performed by the witness of an accident? What are the main reasons of not providing first aid?

\section{MATERIAL AND METHOD}

The study was conducted in the third quarter of 2015 among members of medical rescue teams: system medical doctors, paramedics, system nurses and driver-paramedics who provided medical services in the "Meditrans" Provincial Ambulance and Sanitary Transport Service MRT in Warsaw. During the survey, the headcount was 678 persons in particular medical professions; the distribution was as follows:

- 128 system medical doctors - 42 participated in the study, which was $32.8 \%$;

- 69 system nurses -48 participated in the study, i.e. $69.5 \%$;

- 339 paramedics - 164 participated in the study, i.e. $48.3 \%$;

- 142 driver-paramedics -81 participated in the study, i.e. $57 \%$;

An anonymous questionnaire survey of own design was the research tool that consisted of 12 questions: closed, half open and one open question. Among the questions there were those that characterized respondents in terms of age and gender, as well as questions asking for the medical profession, seniority and the type of team in which they perform medical rescue activities.

\section{RESULTS}

The study involved 335 people, including 258 men (77\%) and 77 women $(23 \%)$, which constituted $49.4 \%$ of the total manpower of all the MRT members providing medical services in PA and STS "Meditrans" Warsaw. Respondents were divided into 3 age groups and by individual medical professions. Table 1 and Figure 1 and 2 present individual distribution by profession, gender and age.

TABLE 1. Characteristics of the study group by profession, gender and age.

\begin{tabular}{|c|c|c|c|c|c|c|c|c|c|c|c|}
\hline & & \multicolumn{2}{|c|}{ Doctors } & \multicolumn{2}{|c|}{ Paramedics } & \multicolumn{2}{|c|}{ Nurses } & \multicolumn{2}{|c|}{$\begin{array}{c}\text { Driver- } \\
\text { Paramedic }\end{array}$} & \multicolumn{2}{|c|}{ All } \\
\hline & & $\mathbf{N}$ & $\%$ & $\mathbf{N}$ & $\%$ & $\mathbf{N}$ & $\%$ & $\mathbf{N}$ & $\%$ & $\mathbf{N}$ & $\%$ \\
\hline \multirow{2}{*}{$\operatorname{sex}$} & K & 13 & $17 \%$ & 30 & $39 \%$ & 30 & $39 \%$ & 4 & $5 \%$ & 77 & $100 \%$ \\
\hline & M & 29 & $11 \%$ & 134 & $52 \%$ & 18 & $7 \%$ & 77 & $30 \%$ & 258 & $100 \%$ \\
\hline \multirow{3}{*}{ age } & $20-29$ & 4 & $1 \%$ & 59 & $18 \%$ & 8 & $2 \%$ & 14 & $4 \%$ & 85 & $25 \%$ \\
\hline & $30-39$ & 14 & $4 \%$ & 87 & $26 \%$ & 9 & $3 \%$ & 29 & $9 \%$ & 139 & $42 \%$ \\
\hline & $>40$ & 24 & $7 \%$ & 18 & $5.5 \%$ & 31 & $9.5 \%$ & 38 & $11 \%$ & 111 & $33 \%$ \\
\hline All & & 42 & $12 \%$ & 110 & $49.5 \%$ & 48 & $14.5 \%$ & 81 & $24 \%$ & 335 & $100 \%$ \\
\hline
\end{tabular}

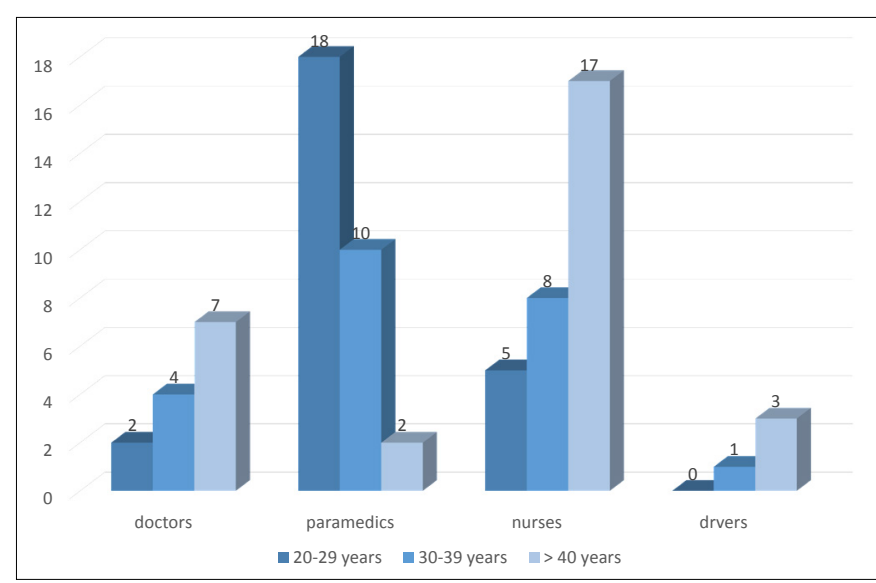

FIGURE 1. Distribution of women in terms of age and profession.

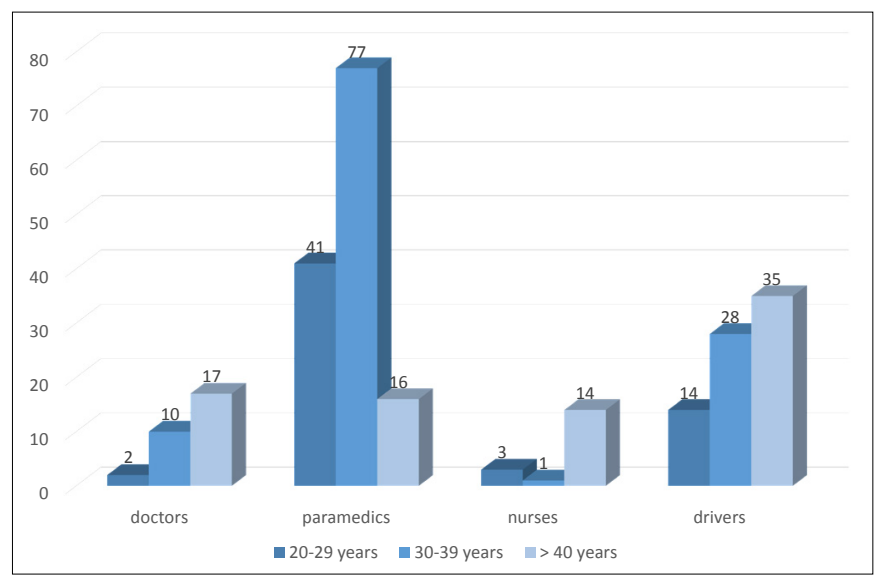

FIGURE 2. Distribution of men in terms of age and profession.

With respect to seniority in the medical rescue teams, the largest group included people who have been active for over 10 years and persons who have been providing medical services for 5-10 years (Table 2), while the least numerous group comprised of people who have been working less than 1 year. 
TABLE 2. Distribution of team members according to seniority.

\begin{tabular}{lcccccccc}
\hline $\begin{array}{c}\text { Seniority } \\
\text { [year] }\end{array}$ & $\mathbf{N}$ & $\mathbf{\%}$ & $\mathbf{F}$ & $\mathbf{M}$ & $\begin{array}{c}\text { doctors paramedics } \\
\mathbf{F} / \mathbf{M}\end{array}$ & $\mathbf{F} / \mathbf{M}$ & $\mathbf{F} / \mathbf{M}$ & $\mathbf{F M}$ \\
\hline$<1$ & 11 & $3.3 \%$ & 3 & 8 & $1 / 2$ & $2 / 3$ & $0 / 1$ & $0 / 2$ \\
\hline $1-3$ & 38 & $11,3 \%$ & 15 & 23 & $1 / 5$ & $13 / 16$ & $1 / 0$ & $0 / 2$ \\
\hline $3-5$ & 46 & $14 \%$ & 11 & 35 & $2 / 3$ & $7 / 21$ & $1 / 1$ & $1 / 10$ \\
\hline $5-10$ & 101 & $30 \%$ & 19 & 82 & $4 / 4$ & $7 / 52$ & $8 / 2$ & $0 / 24$ \\
\hline$>10$ & 138 & $41.2 \%$ & 29 & 109 & $5 / 15$ & $1 / 42$ & $20 / 14$ & $3 / 38$ \\
\hline lack & 1 & $0.2 \%$ & 0 & 1 & & & & $0 / 1$ \\
\hline All & $\mathbf{3 3 5}$ & $\mathbf{1 0 0} \%$ & $\mathbf{7 7}$ & $\mathbf{2 5 8}$ & $\mathbf{1 3 / 2 9}$ & $\mathbf{3 0} / \mathbf{1 3 4}$ & $\mathbf{3 0} / \mathbf{1 8}$ & $\mathbf{4} / \mathbf{7 7}$ \\
\hline
\end{tabular}

The following question concerned the type of team in which they carry out medical rescue activities. Some of the respondents are on duty in both types of MRT, i.e. the specialized and basic units (Figure 3).

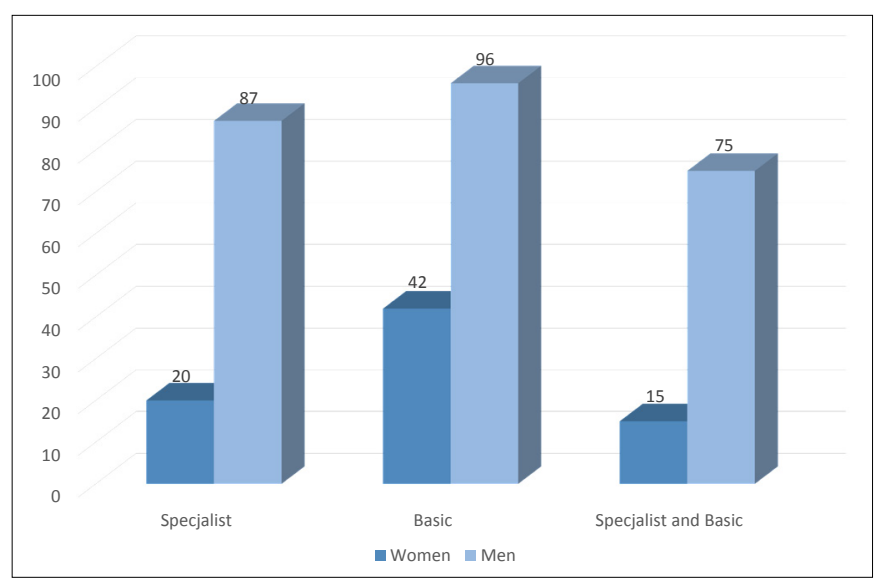

FIGURE 3. Distribution of the type of medical rescue team by gender.

Subsequent questions concerned providing first aid by witnesses while waiting for an ambulance. The vast majority of respondents encountered first aid provision at the scene, but the frequency of such actions was not too high (Table 3 and Figure 4). The most frequently first aid was provided on the street and in homes (Table 4).

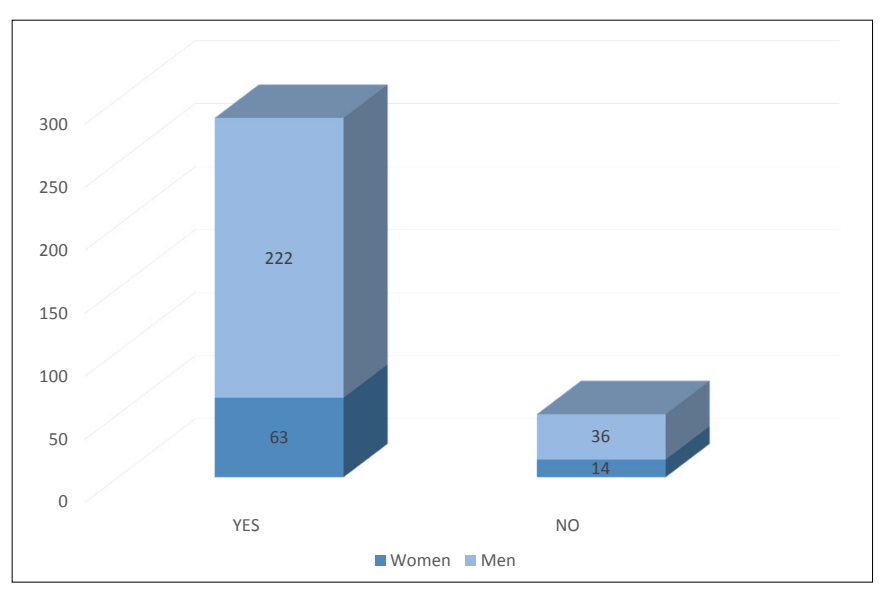

FIGURE 4. The results of MRT members' answers to the question whether you encountered first aid provision by gender.

TABLE 3. Characteristics of first aid provision by MRT profession.

\begin{tabular}{lcccccc}
\hline \hline \multicolumn{1}{c}{ Answers } & doctors & paramedics & nurses & drivers & \multicolumn{2}{c}{ All } \\
\hline always & 0 & 0 & 0 & 0 & 0 & $0 \%$ \\
\hline often & 2 & 11 & 8 & 7 & 28 & $8.36 \%$ \\
\hline sometimes & 37 & 129 & 33 & 65 & 264 & $78.81 \%$ \\
\hline never & 0 & 3 & 1 & 2 & 6 & $1.79 \%$ \\
\hline No answer & 3 & 21 & 6 & 7 & 37 & $11.04 \%$ \\
\hline
\end{tabular}

TABLE 4. Characteristics of first aid provision by the scene of an accident.

\begin{tabular}{lcccc}
\hline \multicolumn{1}{c}{ Answers } & Women & Men & \multicolumn{2}{c}{ All } \\
\hline At home & 17 & 87 & 104 & $31.05 \%$ \\
\hline At work & 9 & 48 & 57 & $17.01 \%$ \\
\hline At school & 5 & 21 & 26 & $7.76 \%$ \\
\hline On the street & 34 & 76 & 110 & $32.84 \%$ \\
\hline other & 12 & 26 & 38 & $11.34 \%$ \\
\hline
\end{tabular}

According to our respondents, the largest group providing first aid was middle-aged people (Table 5).

TABLE 5. Characteristics of persons who provided first aid by the age.

\begin{tabular}{lcccccc}
\hline \multicolumn{1}{c}{ Answers } & \multicolumn{2}{c}{ doctors paramedics nurses } & drivers & \multicolumn{2}{c}{ All } \\
\hline Elder people & 1 & 3 & 3 & 1 & 8 & $2.39 \%$ \\
\hline Middle-aged people & 25 & 91 & 23 & 51 & 190 & $56.72 \%$ \\
\hline Children/Youth & 12 & 49 & 16 & 22 & 99 & $29.55 \%$ \\
\hline No answer & 4 & 21 & 6 & 7 & 38 & $11.34 \%$ \\
\hline
\end{tabular}

ERC guidelines emphasize the importance of medical dispatcher contact with a person requesting assistance. According to Polish law, medical dispatcher's responsibilities are to instruct witnesses in terms of first aid. During the survey respondents were asked the question whether medical dispatcher instructed the person providing first aid on the phone before the arrival of MRT. As many as $36.1 \%$ of the respondents answered YES, while the largest group included people who responded I DO NOT KNOW (37.6\%) (Figure 5).

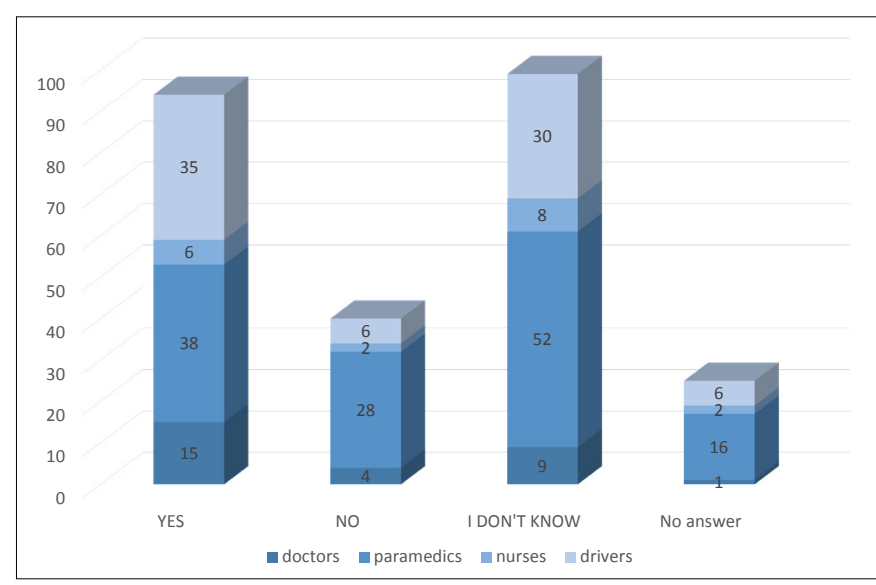

FIGURE 5. Characteristics of an answer to the question whether medical dispatcher instructed the witnesses on first aid while waiting for MRT by the profession.

Another question answered by respondents was related to what specific actions were performed in order to rescue the injured person while waiting for the ambulance (Table 6). Placing in the recovery position was selected by more than $60 \%$ of the respondents, resuscitation by about $20 \%$, clearing the airway by about $4 \%$. The most frequently listed responses to "other, what kind?" included: ensuring patient's comfort, administration of drugs, stopping the bleeding, securing injuries, lifting the legs up, applying dressing, immobilization, calling an ambulance, watching the patient as well as recording videos and taking pictures with a phone. 
TABLE 6. Medical activities provided by witnesses while waiting for medical rescue team.

\begin{tabular}{lcccccc}
\hline \hline \multicolumn{1}{c}{ Answers } & \multicolumn{1}{c}{ doctors paramedics nurses } & drivers & \multicolumn{1}{c}{ All } \\
\hline $\begin{array}{l}\text { Laying in the recovery } \\
\text { position }\end{array}$ & 28 & 101 & 26 & 54 & 209 & $62.39 \%$ \\
\hline Airway access & 2 & 5 & 3 & 4 & 14 & $4.18 \%$ \\
\hline Start CPR & 7 & 34 & 11 & 18 & 70 & $20.89 \%$ \\
\hline Others & 2 & 12 & 5 & 2 & 21 & $6.27 \%$ \\
\hline No answer & 3 & 12 & 3 & 3 & 21 & $6.27 \%$ \\
\hline
\end{tabular}

The final fairly important element was the reason for not provididing first aid by witnesses in the opinions of medical teams members. In this question, which was an open question, respondents were asked to list the reasons for not taking any action while waiting for an ambulance (Table 7). Over 50\% of respondents did not answer. The most common answers were: fear, lack of knowledge and skills, reluctance, indifference, lack of training, lack of experience and fear of doing harm.

TABLE 7. Characteristics of answers to the question what are the reasons for not performing rescue operations by witnesses waiting for an ambulance.

\begin{tabular}{lcccc}
\hline \multicolumn{1}{c}{ Answers } & Women & Men & \multicolumn{2}{c}{ All } \\
\hline Fear & 14 & 26 & 40 & $11.94 \%$ \\
\hline Lack of knowledge and skills & 16 & 48 & 64 & $19.1 \%$ \\
\hline Reluctance and indifference & 2 & 12 & 14 & $4.18 \%$ \\
\hline Fear of assistance & 1 & 5 & 6 & $1.79 \%$ \\
\hline Lack of training & 2 & 7 & 9 & $2.69 \%$ \\
\hline No experience & 1 & 4 & 5 & $1.49 \%$ \\
\hline The fear of harming sb & 1 & 8 & 9 & $2.69 \%$ \\
\hline No answer & 40 & 148 & 188 & $56.12 \%$ \\
\hline All & $\mathbf{7 7}$ & $\mathbf{2 5 8}$ & $\mathbf{3 3 5}$ & $\mathbf{1 0 0 \%}$
\end{tabular}

\section{DISCUSSION}

In emergency situations the behavior of witnesses determines the chances of the person for complete recovery. Not only starting up an emergency medical system by calling MRT, but the type of pre-medical aid provided is important for further therapeutic process of the patient. The study of Adamczyk et al., conducted in persons applying for a driving license indicated that more than half of them would limit the first aid only to calling emergency services despite the knowledge of pre-medical aid principles [13]. In our survey, over $60 \%$ of respondents noted arrangement of the victim in the recovery position, and $20 \%$ of respondents encountered the situation when cardiopulmonary resuscitation had been started while waiting for MRT. Rasmus et al. found that only 19\% of witnesses joined to help in life-threatening situations [14]. In our study, the majority of respondents stated that sometimes (78.81\%) they encounter first aid provision by witnesses of an accident. According to them, the pre-medical actions are not taken due to anxiety (11.94\%) or lack of knowledge and skills (19.1\%). However, it is surprising that $56 \%$ of respondents were unable to determine why there are no actions taken related to the principles of first aid by witnesses of an accident. Interesting was the fact that members of MRT, irrespective of gender, qualified taking pictures and videos as first aid. On the basis of the data on the site of ambulance assistance, street and home are the places where most respondents (approx. 30\%) encountered other activities related to first aid than solely a phone call.

\section{CONCLUSIONS}

1. The majority of respondents have encountered instances of first aid provision, but respondents assessed the frequency of such situations as low.

2. Placing the victim in the recovery position is the simplest and most common form of first aid. Therefore, training should be introduced not only on CPR but also in the scope of helping persons who do not have a sudden cardiac arrest in health emergency.

3. A statement which can be formulated as a main conclusion of the analysis that only continuous education and in particular, practical trainings will help people to overcome the barrier of their limitations in order to help others. Among the largest group of witnesses providing first aid are the elderly and youth who are subjected to various forms of education related to first aid provision.

\section{REFERENCES}

1. Dz. U. 2006, nr 191, poz. 1410.

2. Dybowska I. Udzielanie pomocy to obowiązek moralny. Kronika mazowiecka; 2015;6:24-7.

3. Chemperek E, Goniewicz M, Włoszczak-Szubzda A, et al. Poziom wiedzy uczniów szkół ponadgimnazjalnych i studentów w zakresie pierwszej pomocy. MONZ. 2011;17(4):174-9.

4. Patryn R, Żysko M, Sobczyńska M. Analiza poziomu wiedzy i znajomości prawa dotyczącego zasad udzielania pierwszej pomocy wśród grup aktywnych kierowców województwa lubelskiego. Med Og Nauk Zdr. 2012; 18(4): 324-9.

5. Olejniczak D, Miciuk D, Religion U. Ocena stanu wiedzy studentów Warszawskiego Uniwersytetu Medycznego na kierunku pielęgniarstwo na temat udzielania pierwszej pomocy przedmedycznej. Piel Zdr Publ. 2013;3(2):101-10

6. Grześkowiak M, Frydrysiak K. Wiedza młodzieży szkolnej i studentów pierwszego roku z zakresu udzielania pierwszej pomocy. Now Lek. 2007;76(5):402-5.

7. Strzyżewska K, Medrzycka-Dąbrowska W, Dąbrowski S, et al. Ocena poziomu studentów aglomeracji trójmiejskiej z zakresu udzielania pierwszej pomocy. Anest Ratow. 2012;6:41-52.

8. Greif R, Lockey AS, Conaghan P, et al. European Resuscitation Council Guidelines for Resuscitation 2015 Section 10. Education and implementation of resuscitation. Resuscitation. 2015;95:288-301.

9. Kubiak K. Pierwsza pomoc - wspólna sprawa. Na ratunek. 2009;2:26-7.

10. Stebelski M. Na ratunek pierwszej pomocy. Na ratunek. 2009;2:20-5.

11. Perkins GD, Handley AJ, Koster RW, et al. European Resuscitation Council Guidelines for Resuscitation 2015 Section 2. Adults basic life support and automated external defibrillation section Collaborators. Resuscitation. 2015;95:81-99.

12. Zideman DA, De Buck EDJ, Singletary EM, et al. European Resuscitation Council Guidelines for Resuscitation 2015 Section 9. First aid. Resuscitation. 2015;95:278-87.

13. Adamczyk K, Lorencowicz R, Trawka H. Znajomość zasad udzielania pierwszej pomocy osobom poszkodowanym w wypadkach drogowych. Zdr Publ. 2003;113(3/4):337-40.

14. Rasmus A, Machała W, Samborska-Sablik A. Udział świadków zdarzenia w czynnościach resuscytacyjnych. Zdr Publ. 2002;112(4):475-9.

\section{Corresponding author}

Aneta Binkowska

61 Żwirki i Wigury St., 01-092 Warszawa

E-mail: aneta.binkowska@wum.edu.pl

tel: 225720539 